\title{
Presence Energy, the Main Goal of the Actor's Training
}

\author{
Nicola Camurri \\ Christian Zecca \\ Università di Genova - Genoa, Italy
}

ABSTRACT - Presence Energy, the Main Goal of the Actor's Training - What is charisma? What is that attracts viewer's attention? What characterizes the capacity to act? These questions challenged many people. Following the suggestion made by those questions, we provided a series of experiments aimed to prove the existence of a Presence Energy that, by means of training and rehearsal, is able to change the proprioception of the trained person and his power of observation. It is not a coincidence that many authors and researchers tried to deepen the connection with mysticism and faith. This Presence Energy's existence interested lots of aspect above the theatrical one: it could become a path for charisma and awareness.

Keywords: Presence Energy. Neuroendocrinology. Neuroscience. Organic Actor. Physiology.

RÉSUMÉ - Présence de l'Énergie, l'Objectif Principal de la Formation de l'Acteur Qu'est-ce que le charisme? Qu'est-ce que l'attention de actract spectateur? Qu'est-ce que la capacité d'agir caractérisent? Les réponses sont foundamental pour de nombreux aspects égards au-dessus de celui du théâtre. La plupart des recherches ont été faites sur les aspects esthétiques et pratiques exécution sur les structures du texte. Certains auteurs et certains chercheurs ont réussi à comprendre la connexion avec le mysticisme et la foi. Aujourd'hui, la frontière de la recherche est de trouver des preuves empiriques, à la fois scientifique et physiologique qui représente une méthode pour produire notre temps: l'ère des connexions numériques. Le corps ne sera pas oublié: évolue.

Mots-clés: Energie de Présence. Neuroendocrinologie. Neurosciences. Acteur Organique. Physiologie.

RESUMO - Energia da Presença, a Meta Principal do Treinamento do Ator - O que é carisma? O que atrai a atençáo do espectador? O que caracteriza a capacidade de atuar? Essas perguntas desafiaram muitas pessoas. As respostas sáo fundamentais para muitos aspectos além do teatral. A maioria dos estudos foi feita sobre aspectos estéticos e práticos, sobre estruturas de interpretação do texto. Alguns autores e pesquisadores conseguiram compreender a conexão com o misticismo e a fé. Atualmente, a fronteira da pesquisa é descobrir evidências empíricas, tanto científicas como fisiológicas, para produzir um método que represente nosso tempo: a era das conexóes digitais. $\mathrm{O}$ corpo não esquecerá: ele evolui. Palavras-chave: Energia da Presença. Neuroendocrinologia. Neurociência. Ator Orgânico. Fisiologia. 
What matters to me is that one actor can stand motionless on the stage and rivet our attention while another does not interest us at all. What is the difference? Where chemically, physically, psychically does it lie? Star quality, personality? No. That's too easy and is not an answer. I don't know what the answer is. But I do know that it is here: in this question we can find the starting point of our whole art. Peter Brook, The Shifting Point.

Peter Brook's question has several interesting features for anyone wondering about stage acting, but also for those who try to understand why there are humans who seem to have a gift, an extraordinary ability to capture the attention and to practice the action (and not just the stage one). Is there an intangible and invisible power that, whether appropriately evoked and managed, can produce that psycho-physical change (unfortunately too simply attributed to personal talent), which makes that expression hard hitting? To answer this question, we ventured into an experiment - which coincided with Dr. Christian Zecca's work of degree at DAMS (Discipline delle Arti, della Musica e dello Spettacolo - Disciplines of Arts, Music and Entertainment) University of Bologna (Zecca, 2012) - meant to verify the existence of a Presence Energy that, by means of training and rehearsal, is able to change the proprioception of the trained person and his power of observation. The thesis shows that in extraordinary conditions, the subject that has coached his willingness to perception and to a conscious use of Presence Energy, captures the observer's attention just like a magnet physically attracts metal.

This energy can manifest spontaneously in the body-mind of the subject in case of extreme situations: rituals, games in which life is put at risk or by introducing foreign substances or, finally, self-produced by the body in a certain state of trance or so-called enlightenment ${ }^{1}$. The endogenous production can still be activated in the body-mind of an actor in a conscious way. This aware activation disrupts the daily body-mind dualism in favour of the present moment, lived here and now and not postponed, by means of a subtle artifice of thought, in some non-place-time in the past or the future. One of the ideas that inspired our experiment is the work of Antonin Artaud for whom the secret of this potential condition of the human being is hidden in the silence of breath. Overawed by his words, so we do hold our breath to go in the depth and "[...] 


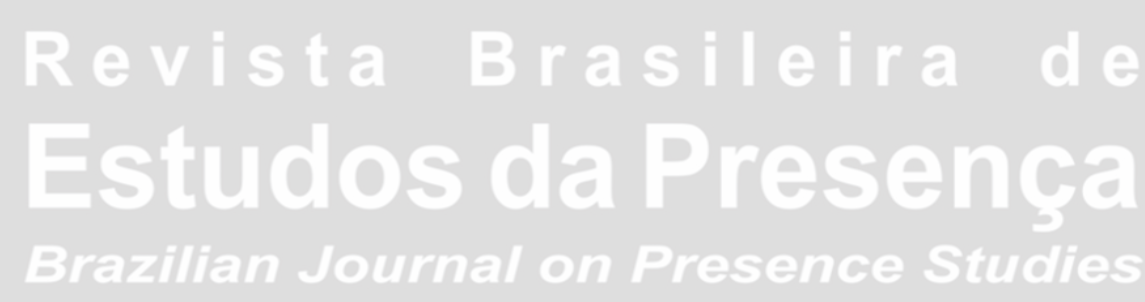

through the hieroglyph of a breath, find an idea of the sacred theatre" (Artaud, 1968, p. 262).

\section{Etymology}

Why Presence Energy (PE)? The etymological proposal of PE arises from the need to highlight the dialectic relationship between the material, physical term presence (as a living human body), and the immaterial term energy ${ }^{2}$. Although the PE cannot materially exist without being hosted in a physical body, it is not a physical energy (bios), powered by a physical training, and subject to decrease and corruption of time. It is instead an eternal and immutable energy (zoe), which by meeting our transient and mortal plane of reality (psyche), makes it eternal. Due to this contact with eternity, our finite being shares experience with the infinite and immortal nature of this energy. The same way our brain provides to the daily decimation of neurons by activating restless new synaptic contacts, the continuous bounce between the terms energy and presence will be an improvement instead of a limit. The Heisenberg uncertainty principle teaches us that we cannot, at the same time, measure mass and energy of a particle because if we stop observing the mass, we cannot know its energy and, if otherwise we measure its energy in motion, we cannot know its physical characteristics. So it might be in our field of study. Considering the mere presence, we will not discover the secret of energy, while working on energy does not clarify the physical characteristics. In short, energy could never coincide with presence, nor the presence with energy; but this dialectic, this eternal need of fusion, is what stoke the presence.

Each tradition has its own theatrical language to tell whether the actor is working or not for the audience. There are several terms to define this operation. In the Western world, it is often called energy, life or simply presence of the actor. Asian theatrical traditions use other words. We find expressions such as: prana or shakti in India; $k o s h i$ (which in Japanese defines the hips area), ki-ai (deep harmony of spirit and body; pneuma; breath), and yugen in Japan; chikara (strength, power achieved through regular exercise of the actor), taksu (heavenly inspiration taking possession of the dancer apart from his will), banyu (increase and decrease of a force raising the whole body and whose complement generates life, breath, wind) in Bali; kung 
fu (hard work) in China (Barba; Savarese, 1996, p. 52-53). After this blink on the terms used in the East, in our research we would like to bring attention to the numerous attempts to investigate this quality of energy in the West, being this a cultural matrix, and also the humus from which it was born and in which the idea of the Presence Energy has developed. This cosmic vital energy that only the actor-dancer can feel and not produce, might have a bearing on what physicists call plasma.

A highly ionized gas has a behaviour that makes it distinguishing from the common material state; for this reason, when the ionization of the gas is almost complete, we can speak of a fourth state of matter, the state of plasma. This state, hardly achievable in the laboratory, is very common in nature: it is the stellar material state (Pasquarelli, 1990, p. 40).

A correct work in the training of the actor-dancer should be checked by an increase of negative ionization of the blood ${ }^{3}$.

Most studies in different fields bring back to the idea of an alien energy that our body-mind, in certain conditions, could be able to use. This energy, leaving the body at the moment of death, has a strong analogy with the concept of soul. In ancient times, before being thought as a purely spiritual substance and before being Platonic and Catholic, the soul was meant as a continuous flow animating movements and life of animals and humans. In many languages, soul is indicated by words relating to the breathing, or the slight fluttering of wings: atman (Sanskrit), pneuma (Greek), spiritus (Latin). In many cultures the body is compared to a percussion instrument: the soul is the heartbeat, the vibration, the rhythm. This wind - vibration or rhythm - can change its face, while remaining itself, for a slight change of its internal tension. Boccaccio, commenting on Dante, said that when anima - the alive and intimate wind - wishes something external, it tends towards it, then it turns into animus (Latin for breath, breathing). In Genesis 1,2, "[...] and the Spirit of God moved upon the face of the waters" (Zecca, 2012, p. 16), the concept of spirit, in this case, is expressed by the Hebrew word ruach (חור), which also means breath. We are seduced by Artaud's thought, who, perhaps first in theatre, uses this term with a practical value, and follows this suggestion. We agree with him when saying that: "[...] the awareness that the soul has an outlet in the body, can make us reach the soul in the opposite direction, and find 
again the essence thanks to mathematical analogies" (Artaud, 1968, p. 244). Well aware of the big difference between soul and spirit, quite arbitrarily, for practical purposes, we lower the thought of Artaud from metaphysics to physics and we look for the secret of Presence at the point of contact between body, mind, and spirit. Yet Artaud suggests, as a keystone of the structure of the human machine, a secret contact between body and mind that he sees as "[...] hidden in the silence of breath" (1968, p. 244). And if the soul, according to Kabbalistic teachings, is fertilized by desire, in its etymology (ruach) it is akin with the breath. Thus, we will try to extend even further the intuition of the poet of the French scene, and give strength to the idea that breath, acting as a bridge between mind and body, can be reconnected with the primary respiration, which has been recently recognized. Breath meant as a bridge of information connecting body, mind, and spirit.

\section{A Neuroscientific Research?}

Born from a theatre and artistic suggestion, our research, in addition to a first empirical confirmation in the experiments described above, has also had a number of natural connections with scientific and para-scientific projects. Although there are strong doubts in the scientific community about the value of some research, we quote here some projects of great interest for our training.

A recent discipline, psiconeuroendocrinoimmunology ${ }^{4}$ (PNEI), starting from Reich's idea ${ }^{5}$ of a strong relationship between mind and body, supports that sexuality and spiritual awareness have the same psycho-chemical course. PNEI studies the relationship between mind, emotions, endocrine system, immune system, and states of consciousness specially minding to their chemical mediation, in order to demonstrate their psycho-chemistry interdependence. This new discipline correlates the various body systems and, according to it, we think that making sex with a feeling of love would lead to a kind of expansion of consciousness. We find interesting the intuition, certainly suggested by Reich, that pleasure, love, and spirituality stimulate the immune system. His revolutionary idea was considered crazy and dangerous, especially in the USA, where his attempt to build a never completed orgone accumulator, able to stimulate orgone in the body, sent him to prison. His chief disciple, Alexander Lowen, starting from studies of his predecessor, comes to postulate 
the existence of a vital energy of the human body in the basic in life, which he calls bio-energy (Lowen, 2003, p. 21). His definition of eros - as a manifestation of the energy of the field - has many points of contact with our experimental work (Lowen, 2003, p. 76). Lowen refers the term bioenergy to a vital energy basis, common to all living beings, which would be present in the body, leaving it at the time of death. The power of presence therefore takes its starting point from the basic vital energy, without which life would not exist in the body.

In short, what seems clear now is that in order to proceed in the direction of a workout Energy Presence, as well as to investigate precisely our actor machine in a neurophysiological level, we must counter the ancient dualism of body/soul or even more simply, the body/mind and, while continuing to separate terms for both operational and conceptual reasons, try to understand to what extent physical and mental affect each other. The science comes to the rescue on this point. The final hammer blow to the traditional separation between the three systems - the nervous, the endocrine, and the immune - came in 1989 by J. Edwin Blalock, professor of physiology at the University of Alabama. He demonstrated that not only the three systems communicate, but that communication is bi-directional: it goes from the brain to the cells responsible for the immune defense and from these again to the brain, as well as from the brain to the immune and endocrine cells and vice versa. Psiconeuroendocrinoimmunology was born.

Interesting experiments were performed by Dr. William Sutherland at the beginning of the twentieth century using a helmet of his own invention, which could vary and control the pressure on different parts of the skull. On the anatomical evidence of a mechanical connection between the skull and sacrum, which precisely allows the transmission of the movement of both structure, he developed the concept of a cranial-sacral system. Indeed, the skull and sacrum are connected by insertions of the dura mater, the thickest and the outermost of the three meninges, which is adherent to the bony structures in the skull, and that fits in a significant way on C2, the second cervical vertebra, and S2, the second sacral vertebra. This determines a movement that involves the body, through the basis of the skull and sacrum pair, which produces movements of expansion or 
decline and return or extension of the skull with different frequency from the heart and the respiration, amounting to eight-fourteen cycles per minute.

The definition of a so anchored to the physical plane training for the actors' mind and body, aimed at developing the ability to feel and therefore be permeated by this energy, will never proceed regardless of also proceeding in the direction of an increasing of the proprioception, both physical and mental. When it comes to control of autonomic functions (the ability to voluntarily change the pace and heart rate, blood pressure, gastric acidity, electrical rhythms in the brain etc.), doctors are normally skeptical, or refer to techniques as Eastern meditation. This setting is still in force in our faculty of medicine where one studies texts of physiology that, after the traditional distinction between the somatic nervous system and autonomic nervous system, generically informed of the possibility to change, even with Western techniques, the typical vegetative functions. In fact, it is from the 1960s that experimental data have been accumulated, first on animals and then on humans, showing that almost all of the visceral functions, which are under the control of the autonomic nervous, may be, to some extent, controlled voluntarily after appropriate training.

The technique in this regard used in Western laboratories is called biofeedback. Biofeedback (or biological feedback) is a process in which people learn to improve their health and performance by observing, through electronic equipment, the signals generated by their body. The neuroendocrinology was born virtually at the end of the 1920s when two scientists, Ernst and Berta spouses Ernst and Berta Scharrer, showed that some neurons of the hypothalamus produce hormone like substances. Twenty years later were identified close relationships between the hypothalamus and the pituitary gland, the endocrine gland that plays a central role in the whole hormonal system. The strong link between the brain and those that still were called glands of internal secretion was then identified. The development of the techniques of electronic microscopy and the application of particular visualization techniques (such as fluorescence and immunohistochemistry) to the brain and nervous tissues in general around the early 1970s, allowed to identify about fifty substances called peptides or neuropeptides. The neurons in 
general, so - and not just those of the hypothalamus - appear as cells capable of releasing neurotransmitters and neuropeptides. But the most shocking in recent years was that the peptides are produced not only by neurons but also by endocrine cells and the immune system.

Neuroscience and PNEI show that the brain, although obviously the site of human intellectual functions, is not at all comparable to a computer in its way of reading the external reality. However, at the same time and to all intents and purposes, it is a large endocrine gland, thereby providing a brilliant idea of the ancient Western medicine - "The brain is a gland, such as the breast", Hippocrates (1983, p. 44) - and Eastern Europe (Zecca, 2012, p. 20) - the brain is the lake of the bone, traditional Chinese Medicine. Thus, the immune system can be called a true sense organ, arranged in a network to monitor both the exterior and the interior. The existence of a series of active molecules at both central (in the brain) and peripheral (in the metabolism of various organs and organ systems) unifies, so to speak, the human body, as a bridge between the brain and the rest of the body, between mind and body biologically joined. With the neuropeptides, to use a happy expression of Paolo Pancheri, they found "[...] the words and phrases of the communication between the brain and the rest of the body" (1979, p. 24). The PNEI marks the end of the old nineteenth century medicine, still lingered on the mechanistic system, which sees the disease as a product of linear external aggression, bacterial or viral infection. But with the old medicine disappears even its alter ego, the psychosomatic medicine, with all its uncertain paraphernalia, predominantly psychological.

Aware that this derail on another site, the medical one, would be presumptuous and arrogant for a theatrical research, we truly believe that, at the basis of the most important unusual modification of the psychophysical state of the actor's body/mind, the PE, lies a physical, mental and spiritual training that begins with a very strong self-suggestion. When it is authentically born, it creates a new state of awareness which is not a desire for self-perfection dictated by our ego, but a continuing desire to resemble as much as possible the image that our minds have created of ourselves (the true self, inner self or superconscious, as from time to time has been defined by the various schools or traditions). This feeling of self-generated feeling part of the whole directly affects our mental and physical state. It is precisely 
this self-awareness of himself as a holistic body/mind in place that is trained to perceive - and that makes us capable of being permeated by - the Presence Energy.

The relationship between theatre and neuroscience has recently been investigated carefully and exhaustively by Dr. Gabriele Sofia, who has focused his research on the importance of mirror neurons in the relationship between actor and spectator (Sofia, 2013; Sofia; Folletti, 2009). It has been proven that, just looking at a person who makes a gesture, the viewer activates the same brain areas that work in those who are carrying out the action. A natural identification leads us to consider the actor on the scene as a double of ourselves. This mimetic phenomenon - more evident if the viewer is really able to make the motion proposed by the performer, so when a dancer is watching a dancer, when a rider looks at a motorcyclist and so on - has led to a practical application in an ideomotoric coaching: a training that - only working on the visualization of the individual who actually imagines to be taking that action - perfects the action itself and trains the muscle mass involved in the action without actually using it (this practice is widely used, for example by professional football players forced to stop to train physically for a few months due to an injury at a game).

As seen before, the modern psiconeuroendocrinoimmunology suggests that our nervous system is connected with the endocrine glands and then with the immune system. Therefore, our research aims to investigate all the possible physiological changes inside the viewer, not only those derived from the activation of mirror neurons. The electrical activity of the brain is measured by electroencephalography (EEG). A modification of the electrical activity of the brain (from the state Beta to Alpha, for example ${ }^{6}$ ) actually also determines a modification of the chemistry of the body (easily measurable with specific salivary tests). The magnetic variation will instead be monitored through the use of the Riodoraku test (Vega test $\left.{ }^{7}\right)$.

\section{From the Presence to the Absence: a digital project}

Starting from the experiment that aimed to prove the existence of the PE, our research work is having its fundamental development with the formalization of a project which is now being developed in the Ph.D. dissertation TAO Digital Platform, Digital Humanities 
Research Project 2014-2017. The basis of the theatrical research will be a practical workshop aimed to stimulate biological and electromagnetic field variations in the body of the subject, a new way of understanding the theatrical training on solid physiological basis. During this seminar, a group of people will be in a performative training divided in three levels of work ${ }^{8}$, after which the participants' biostatistical results will be published. The next level of work can be accessed when the subject's physiological data meet the requirements for the transition to the next training level'. The final data collected will be analysed and recorded both at the biological and biostatistical level and crossed with external data - regarding non-actors who have not undergone any specific training - collected in the digital platform established by the project. The scientific/experimental results will therefore be published and disclosed in real time.

TAO Digital Platform proposes a new way of documenting and recording the theatrical experience. Alongside the traditional testimonials of the theatrical event (pictures, videos of the show or of the training to which the actors were subjected, paper documents as the script, the director's notes, the impressions of the audience or the judgment of critics gathered for the event etc.), our platform documents and records what you do not see in the theatre: the invisible relationship between actor and spectator. Medicine, chemistry, and modern neuroscientific discoveries have shown that thoughts, emotions, and sensations actively influence the physiology of the body. Our research - with the assistance of professionals from the medical/scientific field - aims to measure the chemical, electrical, and magnetic response of actors and spectators, defining the basis for determining a true physiology of the theatrical event.

Along with a classic documentation, students or interested people will have access to information and documents stating the type of physiological response of the event on the viewer. In addition to aesthetic value, it will also investigate the physiological value of the show. The real strength of the platform, however, is precisely in the choice of the medium used for the realization of the research: the internet. Integrating the theatrical and scientific research with modern technology, we are able to implement our results and to compare them in real time with similar research carried out in other parts of the world, to receive continuous feedback from teachers, 
researchers, doctors, and professionals of the fields involved in the project who can actively participate, continuously bringing their expertise at the service of research. Last but not least, the project completes its own goal sharing the results obtained: in fact, it is possible for anyone with access to the web to join the project - even without signing up as a participant in the training, or taking part to the theatrical experiment as a spectator - just following the results that will be defined and updated in real time, commenting, providing advice and opinions, recounting experiences relevant to the research. So, the network will be the tool that will allow our project to feed with continuous incitements, additions and, in short, to grow.

\section{The Experiment}

\section{Training Setting}

The $\alpha$ experiments were done on March 16 ${ }^{\text {th }}, 2012$ (7:30 PM11:30 PM) in Via S. Bernardo 19, Genoa. The training (seven days in April 2012, from the $1^{\text {st }}$ to the $8^{\text {th }}$ ) was done in a second time in the country house Caracol, in Viozene - Cuchera (Cuneo, Italy). The $\beta$ and $\gamma$ experiments were done on April 9 ${ }^{\text {th }}$ (9:00 AM-1:00 PM) in Via S. Bernardo 19, Genoa. The experiments, filmed by Alessio Gambaro, were validated by Dr. Fabio Rivieccio.

\section{Subjects}

Ten subjects (five males and five females) were trained. They were chosen according to age and psychological and social behaviour standards of judgment. The subjects were: Davide Aloi (actor), Riccardo Arduini (kung fu and tai chi expert), Chiara Braucher (musician), Silvia De Grandi (actress), Francesco Deri (actor), Francesca Frassetto (actress), Marco Maesmaker (actor), Maria Mantero (actress), Delfina Parodi (musician), and Michele Spanò (actor).

The age range was between eighteen and thirty-seven because in young people the pineal gland is not yet crystallised and it can still produce melatonin and pineoline with our specific training. The subjects were preferentially artists because "[...] they, in their works, tend to use both cerebral hemispheres in a balance; so do 
they, more than other people, in verbal and non-verbal functions" (Fabbro, 2010, p. 359).

The subjects were willing to take part in the experiments and the training because they very motivated to work on themselves. They were actors, dancers, interested in oriental arts etc. The work was coordinated by Christian Zecca (actor and director) and Gianmarco Accarpio (doctor, osteopath).

During the training the subjects were not allowed to drink alcohol, nor to smoke nor to take drugs, and very little verbal communication was tolerated (the exercises were made by imitation). Mobile phones were not allowed during the week. The diet was almost completely vegetarian. The tooth paste was fluoride-free. The setting was far from TV, computer, smog, noise, electric pollution, and electromagnetic waves.

\section{Method}

Each day of training was divided in four parts: 1) morning: a) 6:30-9:30 AM - short psycho-physical training (running and stretching); b) 10:00 AM - breakfast (fruit); c) 10:30 AM - mental training (breath, meditation, visualization); d) 1:00 PM - lunch (vegetables). 2) afternoon: a) 3:00-7:30 PM - physical training in order to eliminate toxins and produce endorphins and growth hormone $(\mathrm{GH})$ (exercises: proprioception, physical posture, removal of automatic reactions, kung fu, yoga, tai chi, qigong, bioenergetic exercises); b) 8:00 PM - dinner (grains and seeds). 3) evening: a) 9:3011:00 PM - exercises in order to extend sensorial perceptions (feeling the sights, suggestion and autosuggestion, through transmission with the help of Zener cards. 4) night: 11:00 PM-6:30 AM - rest and sleep in order to produce melatonin.

\begin{tabular}{|c|c|c|c|}
\hline Experiment & A1 & A2 & Viewer \\
\hline 1 & $\begin{array}{c}\text { NOT trained } \\
\text { actor }\end{array}$ & Mannequin & $\begin{array}{c}\text { Blindfolded/ } \\
\text { pre- } \\
\text { expressive }\end{array}$ \\
\hline 2 & Trained Actor & $\begin{array}{c}\text { NOT trained } \\
\text { actor }\end{array}$ & $\begin{array}{c}\text { Blindfolded/ } \\
\text { pre- } \\
\text { expressive }\end{array}$ \\
\hline 3 & Trained Actor & $\begin{array}{c}\text { NOT trained } \\
\text { actor }\end{array}$ & Expressive \\
\hline
\end{tabular}

Table 1 - Summary table. 


\begin{tabular}{|c|c|c|c|}
\hline Training & A1 & A2 & Viewer \\
\hline$\alpha$ & $\begin{array}{r}\text { NOT trained } \\
\text { actor }\end{array}$ & Mannequin & NOT trained \\
\hline$\beta$ & Trained Actor & $\begin{array}{r}\text { NOT trained } \\
\text { actor }\end{array}$ & NOT trained \\
\hline$\gamma$ & Trained Actor & $\begin{array}{r}\text { NOT trained } \\
\text { actor }\end{array}$ & Trained \\
\hline
\end{tabular}

Table 2 - Summary table.

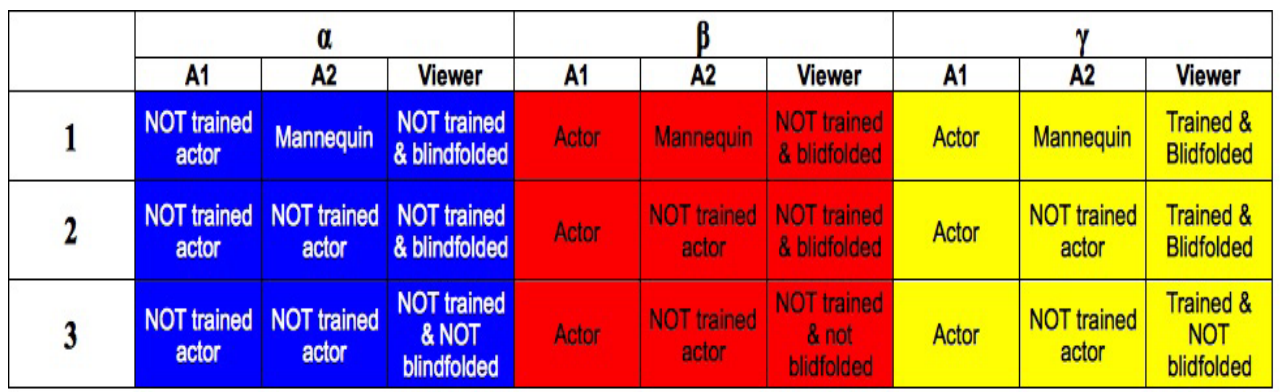

Table 3 - Summary table.

To demonstrate the existence of the Presence Energy and its pre-expressive character ${ }^{10}$, we conducted a series of nine experiments: three of them were based on the real ability of the viewer to detect expressive characteristics, repeated three times with different levels of the PE training. In the first time, called $\alpha$, the test is carried out before any training (with neither the actor nor viewer coached). In the second time, $\beta$, the test is made after a week of training (in which the actors - called $\mathrm{A}$ - were trained to the PE), and finally in the third time, $\gamma$, when the viewer - called $\mathrm{V}$ - has also been trained to the perception of this energy. The $\alpha, \beta$, and $\gamma$ experiments are meant not only to verify the existence of the PE, but to find out whether this energy can be perceived without any training (hypothesis $\alpha$ ), perceived only by training $A$ (hypothesis $\beta$ ), or by training both $A$ and $\mathrm{V}$ (hypothesis $\gamma$ ). With these experiments we investigated the pre-expressive nature of Presence Energy. 


\section{Revista Brasileira o

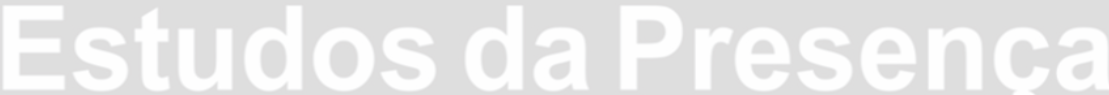 \\ Brazilian Journal on Presence Studies}

\section{Report of the Results of Experiments $\alpha, \beta$, and $\gamma$}

Experiment $1 \alpha$

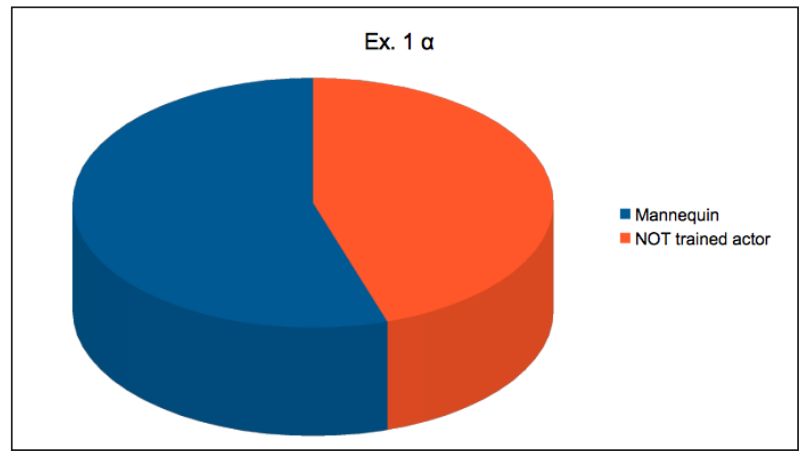

Graph 1 - Viewer's choices.

An untrained viewer $\left(\mathrm{V}^{\prime}\right)$ is blindfolded. In front of him stand a mannequin $(\mathrm{M})$ and an untrained actor $\left(\mathrm{A}^{\prime}\right)$.

$\mathrm{V}^{\prime}$ is asked, ten times during the experiment, to sit blinded in the viewer position and to point in which direction (left or right) he feels or presumes to feel energy or physical presence. The results are reported in the table below. The experiment has been repeated with eight different V's.

Results: on eighty tests, the eight V's pointed out forty-four times to $M$ and thirty-six to A', by a percentage error of $55 \%$. The results of this test can be defined random.

\begin{tabular}{|c|c|c|c|c|c|c|c|c|c|c|}
\hline $\begin{array}{c}\text { EXP. } \\
1 \alpha\end{array}$ & $\begin{array}{c}\text { V'1 } \\
\text { S.D.G. }\end{array}$ & $\begin{array}{l}\text { V'2 } \\
\text { R.A. }\end{array}$ & $\begin{array}{l}\text { V'3 } \\
\text { G.S. }\end{array}$ & $\begin{array}{c}\text { V'4 } \\
\text { M.M. }\end{array}$ & $\begin{array}{l}\text { V'5 } \\
\text { A.P. }\end{array}$ & $\begin{array}{l}\text { V'6 } \\
\text { F.F. }\end{array}$ & $\begin{array}{l}\text { V'7 } \\
\text { F.D. }\end{array}$ & $\begin{array}{l}\text { V'8 } \\
\text { C.S. }\end{array}$ & $\mathrm{n}^{\circ}$ & $\%$ \\
\hline $\begin{array}{c}\text { M vs } \\
A^{\prime}\end{array}$ & 4 vs 6 & 5 vs 5 & 6 vs 4 & 4 vs 6 & 3 vs 7 & 9 vs 1 & 5 vs 5 & 8 vs 2 & $\begin{array}{l}\text { M } 44 \\
A^{\prime} 36\end{array}$ & $\begin{array}{l}55 \\
45\end{array}$ \\
\hline & & & & & & & & TOT & 80 & 100,00 \\
\hline
\end{tabular}

Table 4 - Summary table: viewer's choices.

Note: the experiment $1 \alpha$ shows how $V^{\prime}$ - deprived of the common five senses - is not able to mark any noticeable difference of energy between $A^{\prime}$ and $M$. In fact, $M$ overcomes $A^{\prime}$ by a few points. 


\section{Revista Brastieira o

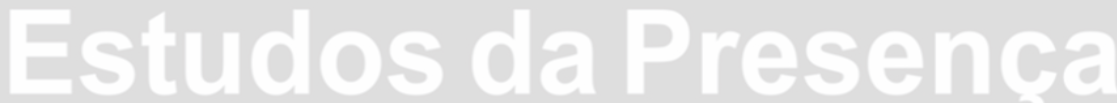 \\ Brazilian Journal on Presence Studies}

E-ISSN 2237-2660

Experiment $1 \beta$

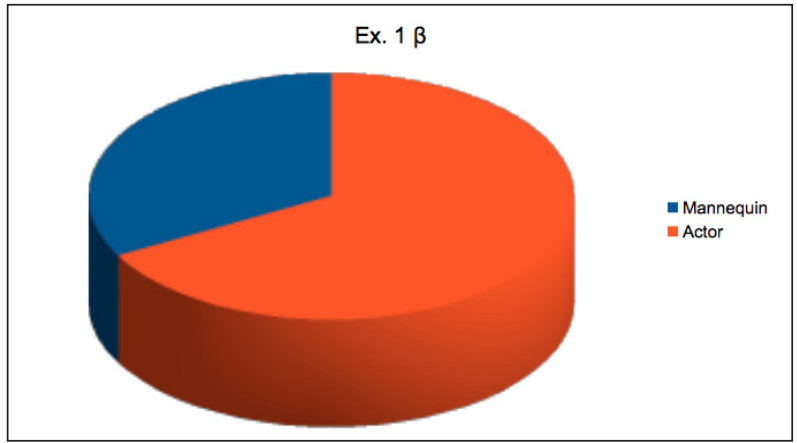

Graph 2 - Viewer's choices.

An untrained viewer $\left(\mathrm{V}^{\prime}\right)$ is blindfolded. In front of him stand a mannequin $(\mathrm{M})$ and a trained actor $(\mathrm{A})$.

$\mathrm{V}^{\prime}$ is asked, ten times during the experiment, to sit blinded in the viewer position and to point in which direction (left or right) he feels or presumes to feel energy or physical presence. The results are reported in the following table. The experiment has been repeated with six different V's.

Results: on 60 tests, the six V's pointed out forty times to A and twenty times to M. A has been pointed by V's twice as much comparing to $\mathrm{M}$.

\begin{tabular}{|c|c|c|c|c|c|c|c|c|}
\hline EXP. $1 \beta$ & $\begin{array}{l}\text { V'1 } \\
\text { G.S. }\end{array}$ & V'2 A.P. & V'3 C.S. & V’4 C.Z. & V'5 F.D. & $\begin{array}{c}\text { V'6 } \\
\text { M.M. }\end{array}$ & $\mathrm{n}^{\circ}$ & $\%$ \\
\hline \multirow[t]{2}{*}{$M$ vs $A$} & 5 vs 5 & 1 vs 9 & 2 vs 8 & 5 vs 5 & 3 vs 7 & 4 vs 6 & $\begin{array}{c}\text { M } 20 \\
\text { A } 40\end{array}$ & $\begin{array}{l}33 \\
67\end{array}$ \\
\hline & & & & & & TOT & 60 & 100,00 \\
\hline
\end{tabular}

Table 5 - Summary table: viewer's choices.

Experiment $1 \gamma$

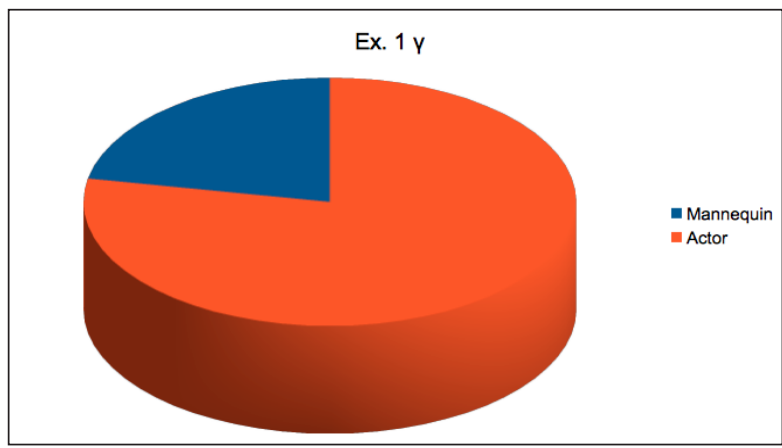

Graph 3 - Viewer's choices.

A trained viewer $(\mathrm{V})$ is blindfolded. In front of him stand a mannequin (M) and a trained actor (A). 
$\mathrm{V}$ is asked, ten times during the experiment, to sit blinded in the viewer position and to point in which direction (left or right) he feels or presumes to feel energy or physical presence. The results are reported in the next table below. The experiment has been repeated with six different Vs.

Results: on sixty tests, the six Vs pointed out forty-seven times to $\mathrm{A}$ and only thirteen times to $\mathrm{M}$. The percentage difference is $56 \%$.

\begin{tabular}{|ccccccccc|}
\hline EXP. & V 1 & V 2 & V 3 & V 4 & V 5 & V 6 & n $^{\circ}$ & $\%$ \\
$\mathbf{1} \boldsymbol{\gamma}$ & R.A. & M.M. & F.F. & F.D. & D.P. & A.P. & & \\
M vs A & 3 vs 7 & 3 vs 7 & 1 vs 9 & 4 vs 6 & 0 vs 10 & 2 vs 8 & M 13 & 22 \\
& & & & & & & A 47 & 78 \\
& & & & & & TOT & 60 & 100,00 \\
\hline
\end{tabular}

Table 6 - Summary table: viewer's choices.

Experiment $2 \alpha$

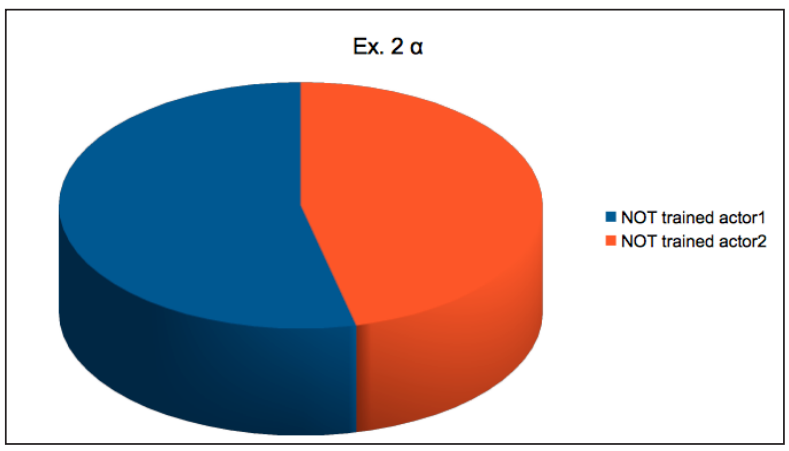

Graph 4 - Viewer's choices.

An untrained viewer $\left(\mathrm{V}^{\prime}\right)$ is blindfolded. In front of him stand two untrained actors (A'1 and A'2).

$\mathrm{V}^{\prime}$ is asked, ten times during the experiment, to sit blinded in the viewer position and to point in which direction (left or right) he feels or presumes to feel energy or physical presence. The results are reported in the following table below. The experiment has been repeated with nine different V's.

Results: on ninety tests, the nine V's pointed out forty-six times to A'1 and forty-four times to A'2. The results of this test can be defined as random as well. 
E-ISSN 2237-2660

\begin{tabular}{|cccccccccccc|}
\hline EXP. & V'1 & V'2 & V'3 & V'4 & V'5 & V'6 & V'7 & V'8 & V'9 & n$^{\circ}$ & $\%$ \\
$\mathbf{2 \alpha}$ & C.B. & F.N. & M.S. & D.P. & G.A. & V.C. & F.P. & A.C. & F.F. & & \\
A' 1 & 2 vs 8 & 5 vs 5 & 7 vs 3 & 8 vs 2 & 3 vs 7 & 4 vs 6 & 7 vs 3 & 7 vs 3 & 3 vs 7 & A'1 & 51 \\
vs A'2 & & & & & & & & & & 46 & 44 \\
& & & & & & & & & & A'2 & \\
& & & & & & & & & & 44 & \\
& & & & & & & & & TOT & 90 & 100,00 \\
\hline
\end{tabular}

Table 7 - Summary table: viewer's choices.

Experiment $2 \beta$

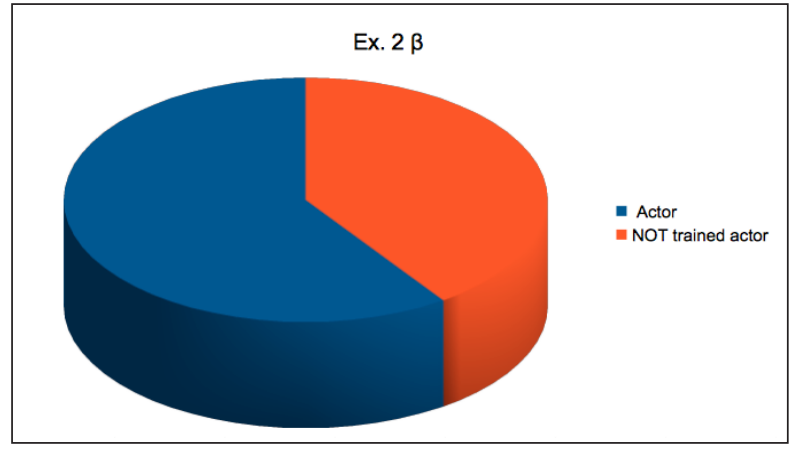

Graph 5 - Viewer's choices.

An untrained viewer $\left(V^{\prime}\right)$ is blindfolded. In front of him stand one trained actor $(\mathrm{A})$ and one untrained actor $\left(\mathrm{A}^{\prime}\right)$.

$V^{\prime}$ is asked, ten times during the experiment, to sit blinded in the viewer position and to point in which direction (left or right) he feels or presumes to feel energy or physical presence. The results are reported in the table below. The experiment has been repeated with six different V's.

Results: on sixty tests, the six V's pointed out thirty-nine times to $\mathrm{A}$ and twenty-one times to $\mathrm{A}$ '. By training $\mathrm{A}$, we got almost twice as much reaction in relation to $A^{\prime}$.

\begin{tabular}{|c|c|c|c|c|c|c|c|c|}
\hline EXP. $2 \beta$ & $\begin{array}{l}\text { V'1 } \\
\text { F.N. }\end{array}$ & $\begin{array}{l}\text { V'2 } \\
\text { V.C. }\end{array}$ & $\begin{array}{l}\text { V'3 } \\
\text { A.G. }\end{array}$ & $\begin{array}{l}\text { V'4 } \\
\text { G.S. }\end{array}$ & $\begin{array}{c}\text { V'5 } \\
\text { U.M. }\end{array}$ & $\begin{array}{l}\text { V'6 } \\
\text { A.P. }\end{array}$ & $\mathrm{n}^{\circ}$ & $\%$ \\
\hline$A^{\prime}$ vs A & 5 vs 5 & 3 vs 7 & 6 vs 4 & 0 vs 10 & 4 vs 6 & 3 vs 7 & $\begin{array}{cc}\text { A' } & 21 \\
\text { A } & 39\end{array}$ & $\begin{array}{l}35 \\
65\end{array}$ \\
\hline & & & & & & TOT & 60 & 100,00 \\
\hline
\end{tabular}

Table 8 - Summary table: viewer's choices. 


\section{Revista Brastieira o

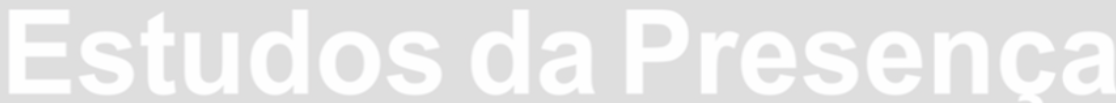 \\ Brazilian Journal on Presence Studies}

E-ISSN 2237-2660

Experiment $2 \gamma$

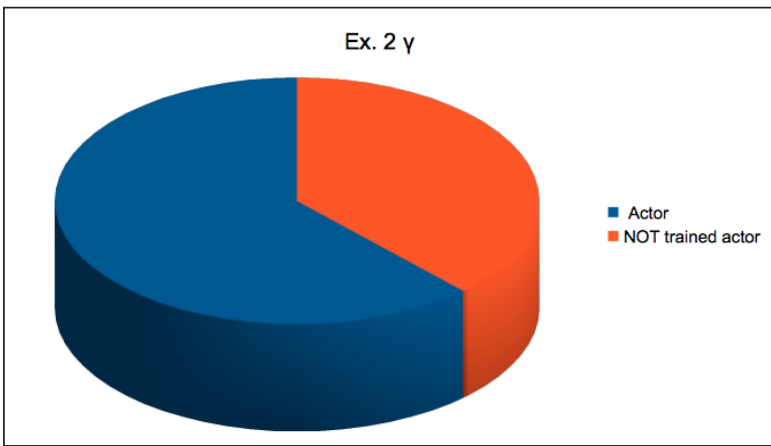

Graph 6 - Viewer's choices.

A trained viewer $\left(V^{\prime}\right)$ is blindfolded. In front of him stand one trained actor $(A)$ and one untrained actor $\left(A^{\prime}\right)$.

$\mathrm{V}^{\prime}$ is asked, ten times during the experiment, to sit blinded in the viewer position and to point in which direction (left or right) he feels or presumes to feel energy or physical presence. The results are reported in the following table. The experiment has been repeated with seven different V's.

Results: on seventy tests, the seven V's pointed out forty-three times to A and twenty-seven times to A'. In spite of the good result, it shows to be easier for $\mathrm{V}$ to feel the difference between a living body and an object rather than between two living bodies.

\begin{tabular}{|c|c|c|c|c|c|c|c|c|c|}
\hline $\begin{array}{c}\text { EXP. } \\
2 \gamma\end{array}$ & $\begin{array}{l}\text { V } 1 \\
\text { C.B. }\end{array}$ & $\begin{array}{l}\text { V } 2 \\
\text { M.S. }\end{array}$ & $\begin{array}{l}\text { V } 3 \\
\text { D.P. }\end{array}$ & $\begin{array}{l}\text { V } 4 \\
\text { F.F. }\end{array}$ & $\begin{array}{c}\text { V } 5 \\
\text { M.M. }\end{array}$ & $\begin{array}{l}\text { V } 6 \\
\text { F.A. }\end{array}$ & $\begin{array}{l}\text { V7 } \\
\text { V.C. }\end{array}$ & $\mathrm{n}^{\circ}$ & $\%$ \\
\hline \multirow[t]{2}{*}{$A^{\prime}$ vs $\mathrm{A}$} & 3 vs 7 & 5 vs 5 & 5 vs 5 & 7 vs 3 & 5 vs 5 & 0 vs 10 & 2 vs 8 & $\begin{array}{c}\text { A' } 27 \\
\text { A } 43\end{array}$ & $\begin{array}{l}38 \\
62\end{array}$ \\
\hline & & & & & & & TOT & 70 & 100,00 \\
\hline
\end{tabular}

Table 9 - Summary table: viewer's choices.

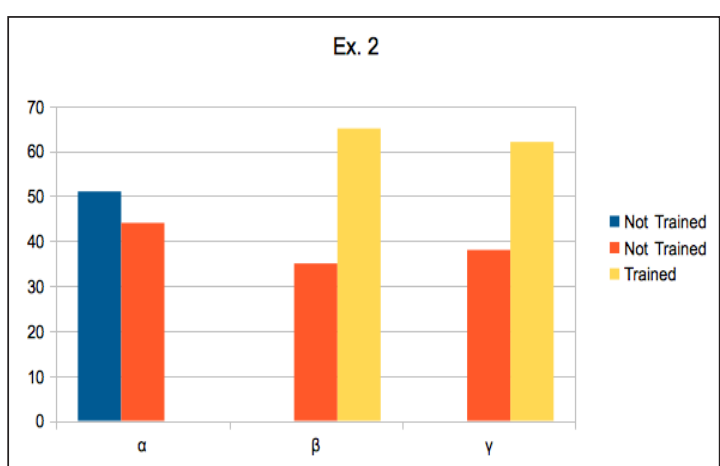

Graph 7 - Summary of the viewer's choices in experiments 2. 


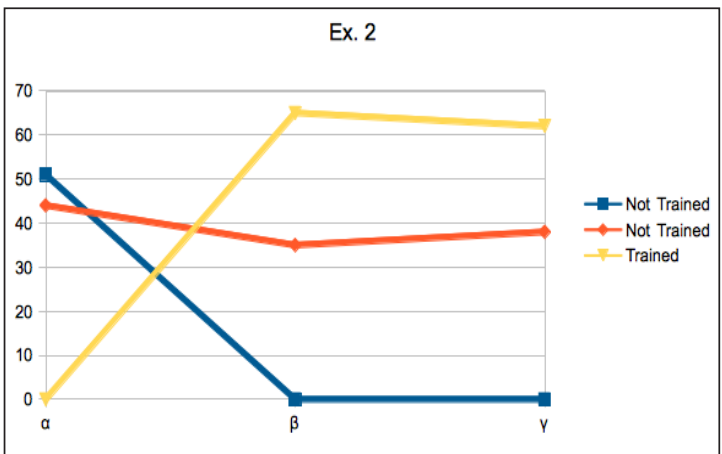

Graph 8 - Progression of the viewer's choices in experiments 2.

Note: the $2 \gamma$ experiment (blind trained viewer) is the most interesting because Presence Energy is more evident than in the $3 \gamma$ experiment (not blinded viewer). Therefore, the postulated preexpressive character is proved by the fact that the viewer is deprived of any commonly recognized sensory function.

\section{Experiment $3 \alpha$}

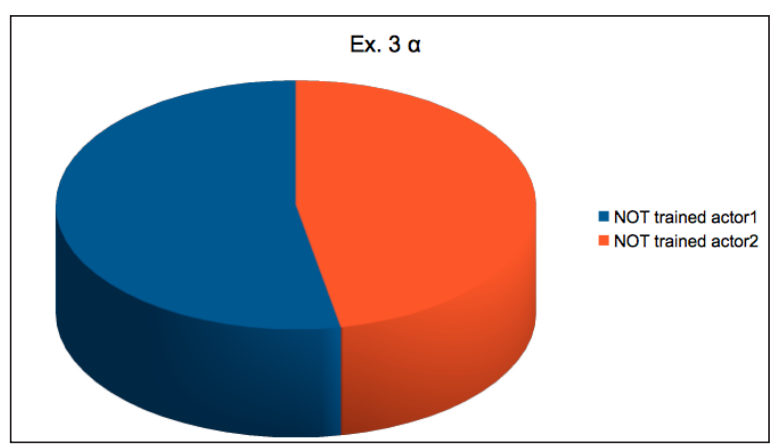

Graph 9 - Viewer's choices.

An untrained viewer $\left(V^{\prime}\right)$ is not blindfolded. In front of him stand two untrained actors (A'1) and (A'2).

$V^{\prime}$ is asked, ten times during the experiment, to sit not blinded in the viewer position and to point in which direction (left or right) he feels or presumes to feel energy or physical presence. The results are reported in the table below. The experiment has been repeated with nine different V's.

Results: on ninety tests, the nine V's pointed out forty-eight times to A'1 and forty-two times to A'2. The results of this test can be also defined as random. 
E-ISSN 2237-2660

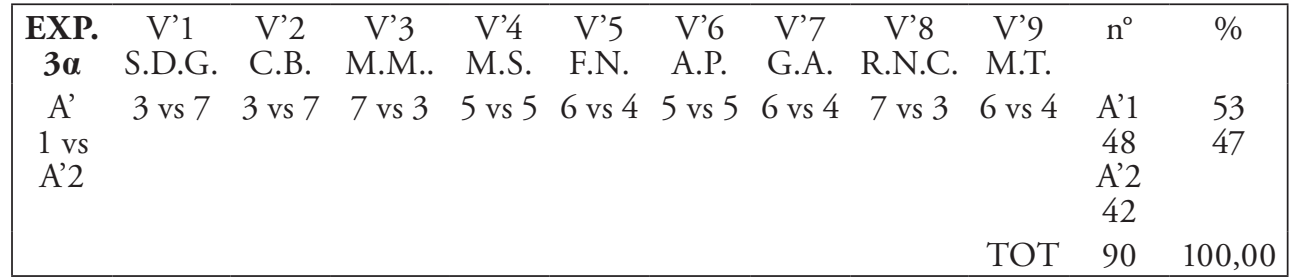

Table 10 - Summary table: viewer's choices.

Experiment $3 \beta$

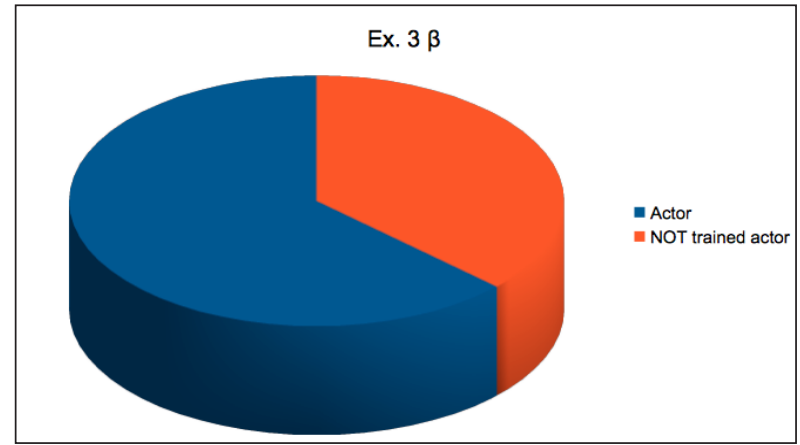

Graph 10 - Viewer's choices.

An untrained viewer $\left(V^{\prime}\right)$ is not blindfolded. In front of him stand one trained actor $(A)$ and one untrained actor $\left(A^{\prime}\right)$.

$V^{\prime}$ is asked, ten times during the experiment, to sit not blinded in the viewer position and to point in which direction (left or right) he feels or presumes to feel energy or physical presence. The results are reported in the following table. The experiment has been repeated with ten different V's.

Results: on a hundred tests, the ten V's pointed out sixty-three times to $A$ and thirty-seven times to A'. By training A only and not $V^{\prime}$, we got almost twice as much reaction in relation to A'.

This experiment, together with the $3 \gamma$, is the answer to the question of Peter Brook.

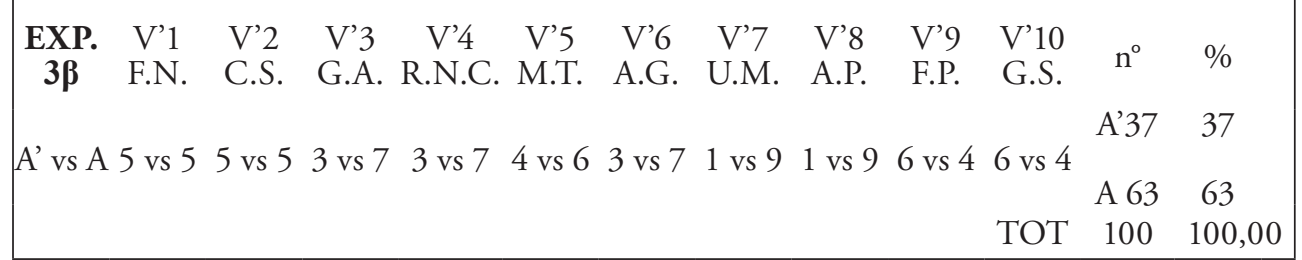

Table 11 - Summary table: viewer's choices. 


\section{Revista Brastieira o

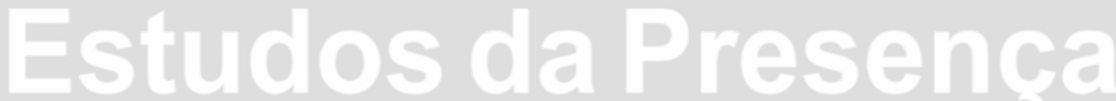 Brazilian Journal on Presence Studies}

E-ISSN 2237-2660

Experiment $3 \gamma$

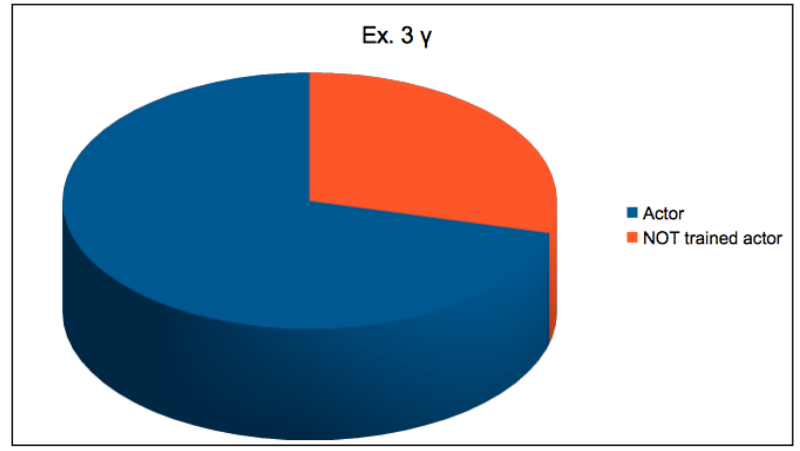

Graph 11 - Viewer's choices.

A trained viewer $(V)$ is not blindfolded. In front of him stand one trained actor $(\mathrm{A})$ and one untrained actor $\left(\mathrm{A}^{\prime}\right)$.

$\mathrm{V}$ is asked, ten times during the experiment, to sit not blinded in the viewer position and to point in which direction (left or right) he feels or presumes to feel energy or physical presence. The results are reported in the table below. The experiment has been repeated with seven different Vs.

Results: on seventy tests, the seven Vs pointed out fifty-five times to A and only fifteen times to A'. By training both A and V, we got almost three times more reaction than $A^{\prime}$.

\begin{tabular}{|c|c|c|c|c|c|c|c|c|c|}
\hline $\begin{array}{c}\text { EXP. } \\
3 \gamma\end{array}$ & $\begin{array}{l}\text { V } 1 \\
\text { C.B. }\end{array}$ & $\begin{array}{c}\text { V } 2 \\
\text { M.M. }\end{array}$ & $\begin{array}{l}\text { V } 3 \\
\text { R.A. }\end{array}$ & $\begin{array}{l}\text { V } 4 \\
\text { M.S. }\end{array}$ & $\begin{array}{l}\text { V } 5 \\
\text { D.P. }\end{array}$ & $\begin{array}{l}\text { V } 6 \\
\text { V.C. }\end{array}$ & $\begin{array}{l}\text { V } 7 \\
\text { C.Z. }\end{array}$ & $\mathrm{n}^{\circ}$ & $\%$ \\
\hline \multirow[t]{2}{*}{$A^{\prime}$ vs $A$} & 3 vs 7 & 1 vs 9 & 0 vs 10 & 6 vs 4 & 1 vs 9 & 2 vs 8 & 2 vs 8 & $\begin{array}{l}\text { A' } 15 \\
\text { A } 55\end{array}$ & $\begin{array}{l}21 \\
79\end{array}$ \\
\hline & & & & & & & TOT & 70 & 100,00 \\
\hline
\end{tabular}

Table 12 - Summary table: viewer's choices.

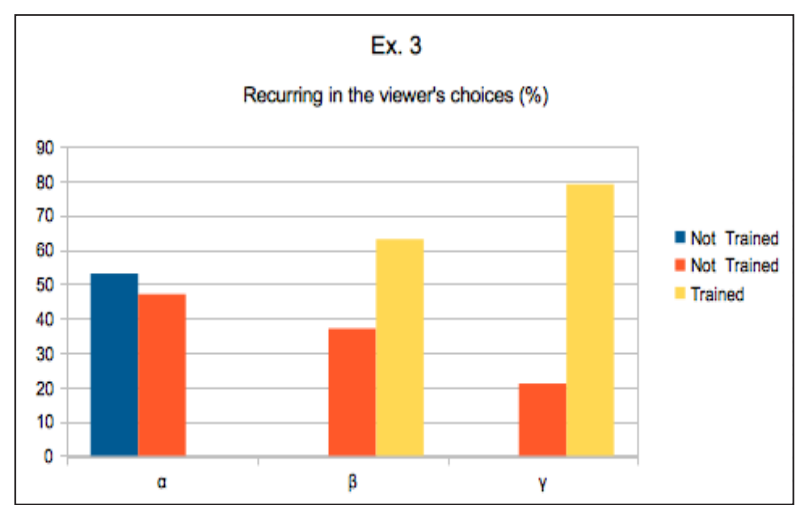

Graph 12 - Summary of the viewer's choices in experiments 3. 
The statistical consistency is not in doubt: in fact, when applying the binomial test in the last experiment analysed, the $3 \gamma$, in seventy trials, the probability of success of fifty-five is about six in a million. The binomial test provides the probability of having $s$ successful events on $n$ independent tests and, in our case, $\mathrm{P}(\mathrm{s} / \mathrm{N})=\mathrm{P}(55 / 70)=$ 6.11117917322199E-07.

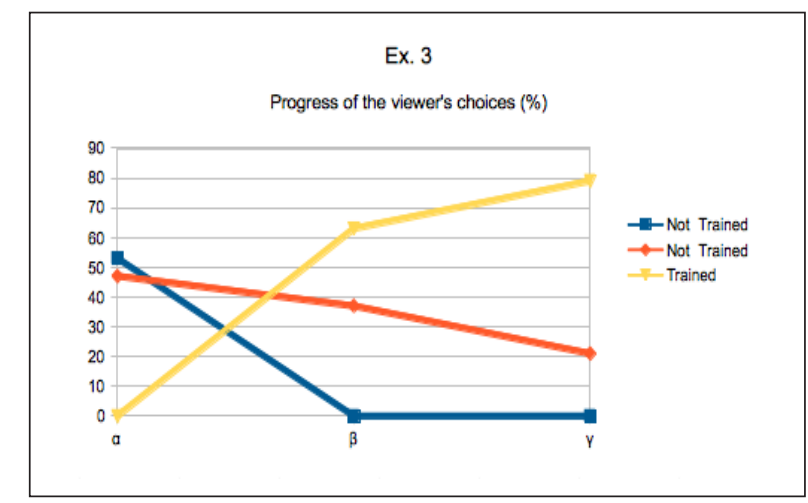

Graph 13 - Progression of the viewer's choices in experiments 3.

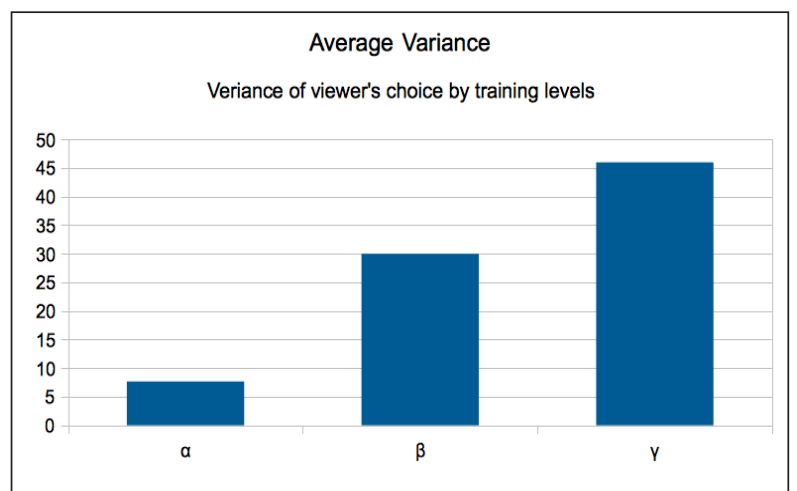

Graph 14 - Variance of the viewer's choices by training levels.

By increasing the training levels, the summary chart Average Variance shows us how we can have a broader differential in the viewer choices: the more the subjects are trained, the more the choice becomes clear. There is a great difference when the actors are trained for the PE perception ( $\beta$ ), but it becomes substantial when also viewers are trained $(\gamma)$. In this case, the test success level is around $80 \%$. This shows that the training allows a condition which, although invisible, does exist and allows the actor dancer to host in his body-mind what we called Power of Presence. 


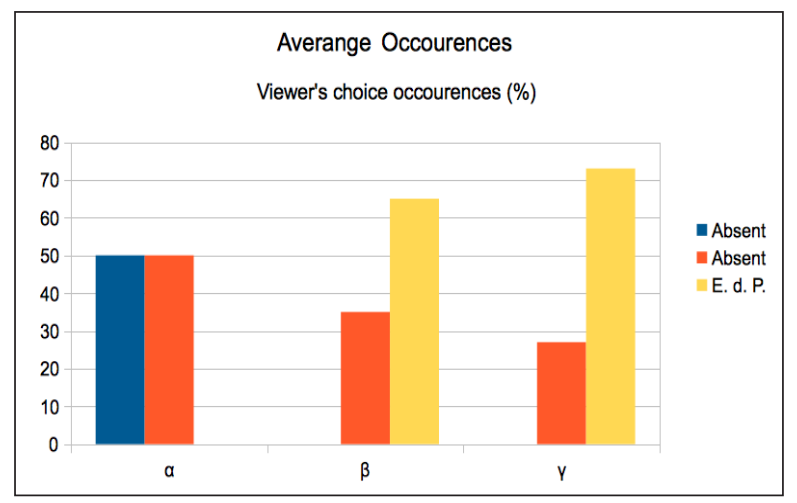

Graph 15 - Average of the viewer's choices.

The chart Average Occurrences shows us how the difference between the choices of bodies deprived of the opportunity to act as a transmitting antenna and conductive materials of PE (whether these bodies are animated or not) is random: about $50 \%(\alpha)$. The viewer with no training recognizes about $65 \%$ of times the actor trained to the perception of the PE $(\beta)$. A coached viewer recognizes more than $70 \%$ of the cases, a trained actor $(\gamma)$.

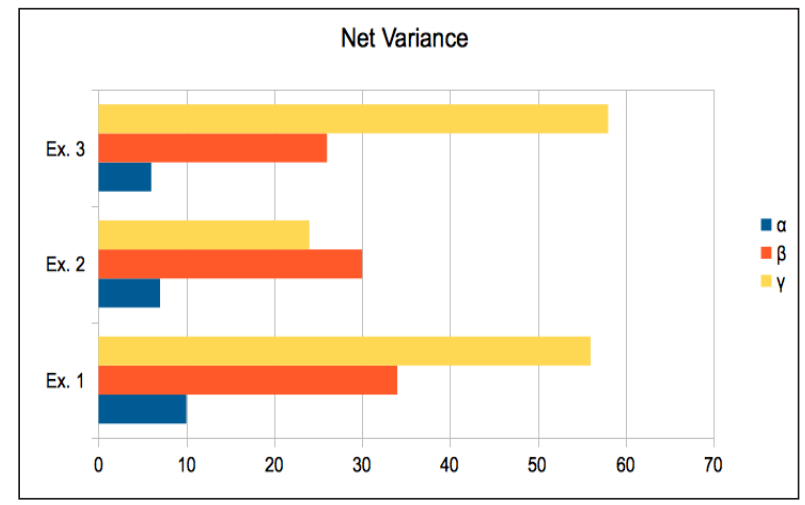

Graph 16 - Variance of the viewer's choices.

Based on the results obtained, we believe that we can state with certainty that the Presence Energy exists and can be trained. In the chart Net Variance we understand how the lack of training affects the recognition accuracy. In fact, the blue column of the experiment $\alpha$ is always shorter than the $\beta$ (orange) and the $\gamma$ (yellow). 


\section{Revista Brasiturita de Estudos da Presence

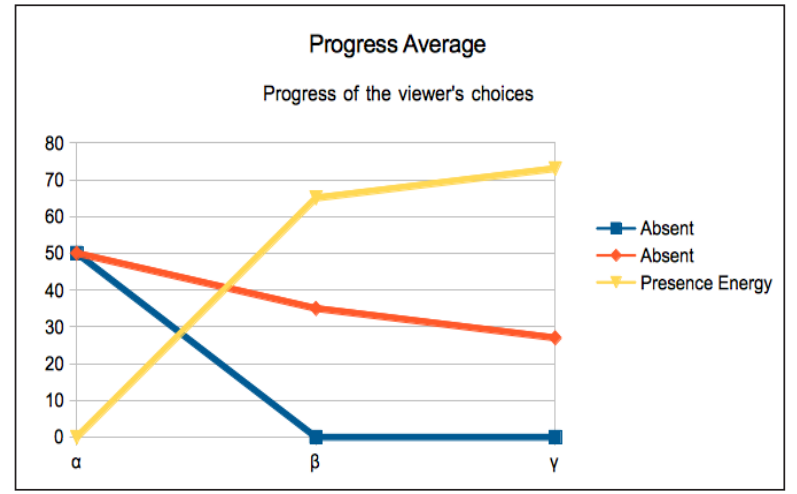

Graph 17 - Progression of the viewer's choices.

In the chart Progress Average it is even more evident how the progression of the choices of the viewer depends on the level of training involved in the experiment. The yellow line indicates the progress of the options concerning the trained actor in relation to the untrained one. In the series of experiments $\alpha$ - not providing any training subject - the PE is in fact absent. When trained subjects (series $\beta$ and $\gamma$ ) are inserted, the training values become decisive.

We are aware that this experiment is only a starting point for a far more structured and complex research. We also believe that the direction is correct and that the results of this experiment deserve a debate and a discussion that goes beyond the mere suggestion that has sparked our research. 


\section{Notes}

${ }^{1}$ The study refers mainly to atrial natriuretic peptide and substances secreted by the pineal gland as melatonin or,according to studies by Rick Strassman, the dimethyltryptamine.

2 "What I propose is to study the presence with the energy and the energy with presence where ever not be able to focus on the center of the cross that the light trails of the two concepts - perpetually in motion - when they meet, determine" (Zecca, 2012, p. 29).

${ }^{3}$ Visit the following website: <http://www.naturopatiaeuropea.it>.

4 "We have identified the connections between the brain, endocrine, and immune system. This means that the relationship between mind and body have left the land of conjecture, pure psychologism. Now, not only the channels of connection between psyche and soma, but also between molecules that act as mediators of this relationship have been identified. Heavens no, we have not entirely clear. Indeed, the journey is just beginning, but the direction is the right one" (Biondi, 2008, p. 9).

${ }^{5}$ Reich is famous for his theories about the orgone, which influenced the theatrical research, among others, the living theatre.

${ }^{6}$ Brain waves are detectable with graphical plots showing the electrical activity of the brain by recording the polygraphic electroencephalogram.

7 The Vegatest Expert is a device through which it is possible to interrogate the body to find the information needed to track down the root causes of imbalances that can cause sickness and disease. In this way, a proper therapy that cures the real cause of the disease and not only the symptoms can be easily set. Quantum physics has shown that only a small part of the universe is matter, while the rest is energy. However, since each form of energy carries information, then we can say that all depends on information: in a healthy organism information are balanced and in constant adaptation to internal and external conditions, while in a sick one information becomes rigid, or rather unable to respond in a coherent way to the stimuli they receive, which makes it impossible to keep the body in balance.

${ }^{8}$ The training is divided into three physiological/performative levels: black protocol, white protocol, red protocol.

${ }^{9}$ Each level of training corresponds to the goals of the physiological results obtained from the analysis.

${ }^{10}$ For what concerns the pre-expressive consider indispensable deprivation of view - as well as the other senses normally understood - as the mere physical appearance - although in idle condition -, which has for us expressive characteristics in contrast to what is claimed by Eugenio Barba for whom the total inactivity or the neutrality of the actor-dancer are considerable pre-expressive. 


\section{References}

ARTAUD, Antonin. Il Teatro e il suo Doppio. Torino: Einaudi, 1968.

BARBA, Eugenio. La Canoa di Carte: trattato di antropologia teatrale. Bologna: Il Mulino, 1993.

BARBA, Eugenio; SAVERESE, Nicola. L’Arte Segreta dell'Attore. Lecce: Argo, 1996.

BAYATLY, Kassim. La Struttura dei Corpi Sottili: il teatro intermediario. Milano: Ubulibri, 2006.

BIONDI, Massimo. Psychosomatic Medicine. In: BONIARDI, Barbara (Ed.). La Scienza Incontra lo Spirito: sessualità e spiritualità. Milano: Macroedizioni, 2008. P. 34-48.

BONIARDI, Barbara (Ed.). La Scienza incontra lo Spirito: sessualità e spiritualità. Milano: Macroedizioni, 2008.

BRIEGEL, Jürgen. Rivelazioni di un Immortale. Cesena: Macroedizioni, 2003.

BROOK, Peter. Il Punto in Movimento 1946-1987. Milano: Ubulibri, 1997.

CAPPELLETTO, Gian Vitorio. Il Corpo come Tempio. Torino: Gruppo di Meditazione Profonda, 1997.

CRUCIANI, Fabrizio; FALLETTI, Clelia. Civiltà Teatrale nel XX Secolo. Bologna: Il Mulino, 1986.

DE SOUZENELLE, Annick. Il Simbolismo del Corpo Umano. Triona: Servitium, 2004. FABBRO, Franco. Neuropsicologia dell'Esperienza Religiosa. Roma: Astrolabio, 2010. FROMM, Erich. L'Arte d'Amare. Milano: CDE, 1988.

GERMAIN, Walter. Il Magico Potere della Nostra Mente. Roma: Mediterranee, 1975. HIPPOCRATES. Testi di Medicina Greca. Bologna: Biblioteca Univesitaria Rizzoli, 1983.

LOWEN, Alexander. Bioenergetica: manuale di esercizi pratici. Milano: Astrolabio, 1979.

LOWEN, Alexander. Il Linguaggio del Corpo. Milano: Feltrinelli, 2003.

MARSHALL, Peter. I Segreti dell'Alchimia. Milano: Mondolibri, 2001.

MISHRA, Rammurti. Principi Fondamentali di Yoga. Bologna: Cappelli, 1973.

OUSPENSKY, Peter Demianovich. Frammenti di un Insegnamento Sconosciuto. Roma: Astrolabio, 1976.

PANCHERI, Paolo. Stress, Emozioni e Malattia. Milano: Mondadori, 1980.

PASQUARELLI, Aldo. Plasma (Physics). Torino: UTET, 1990.

RUFFINI, Franco. I Teatri di Artaud. Bologna: Il Mulino, 1999.

RUFFINI, Franco. Teatro e Boxe. Bologna: Il Mulino, 1996.

SCHWALlER DE LUBICZ, René Adolphe. Il Tempio dell'Uomo. v. 1. Roma: Mediterranee, 2000. 
SHELDRAKE, Rupert. La Mente Estesa. Milano: Urra, 2006.

SOFIA, Gabriele. Le Acrobazie dello Spettatore: dal teatro alla neuroscenza e ritorno. Roma: Bulzoni, 2013.

SOFIA, Gabriele; FOLLETTI, Clelia. Dialoghi tra Teatro e Neuroscienza. Roma: Allegre, 2009.

TRESOLDI, Roberto. Terapie Vibrazionali. Milano: Tecniche Nuove, 2000.

ZECCA, Christian. Energia di Presenza: indagini sul livello pre-espressivo della relazione attore-spettatore. Bologna: Università di Bologna, 2012.

Christian Zecca, attending Ph.D in Digital Humanities, researches on the show and new digital technologies. Formed at the School of Acting La Quinta Praticabile, directed by M. Caputo, he is an acting teacher, and since 2004 president of the School. Founder, with maestro Enrico Bonavera, of the theater company Picpus Theatre. Founder at the Università di Genova of a permanent workshop called Training for the Actor Organic, which deals with the training of the actor to the perception of Energy Presence (www.tao.digitalplatform.it).

Email: christianzecca@libero.it

Nicola Camurri is an actor, a director, and a new media consultant. Graduated in Philosophy at the Università di Genova, specialized in Performing Arts \& Entertainment at EUTHECA Foundation in Rome. Founder and president of Sophia Dalla Notte, a non-profit organization that deals with new jobs and technologies, arts, and culture. He founded the webzine MAGult (www.magult.it). He deals with the direction of the management and production for television programs and live shows and takes care of the communication and social media management for business. E-mail: nicola.camurri@libero.it

This unpublished text, proofread by Ananyr Porto Fajardo, is also published in Portuguese in this issue. 